\title{
Translating Hygge: a Danish design myth and its Anglophone appropriation
}

\author{
Malene Breunig and Shona Kallestrup
}

\section{Summary}

Hygge, the lifestyling trend that offers a path to 'authentic' Danish contentment, is one of the more curious instances of cultural translation in recent years, both semantically and in terms of how an everyday Danish concept has been transformed by London publishing houses into a marketable commodity. Despite the widespread international popular success of the phenomenon, hygge has received little academic attention. What is particularly lacking is an analysis of the cultural transferral of the concept, of the rather different set of meanings constructed by the remodelling of hygge by English-speaking commentators. This paper proposes that design history can offer a helpful framework for this kind of understanding. By approaching the case of hygge as a 'mythology' in the Barthian sense, we will argue that the concept builds upon the legacy of the mythologies imprinted on Anglophone societies by the branding of Scandinavian Design since the 1950s. Highlighting the links between such myths and the manufactured British version of hygge, we will posit that the meaning of hygge - the way it operates as a sign in British culture today - is dependent upon longstanding structures of understanding.

KEYWORDS: hygge, Scandinavian Design, mythologies, mediation, design history, the home

\section{Introduction}

This paper has its origins in observations of student attitudes to hygge, the Danish concept of 'pleasurable enjoyment in a social and spatial interior' which has been mediated by British publishers in recent years as a lifestyling trend. ${ }^{1}$ When hygge was discussed during a module on Scandinavian Design at a British university in spring 2016, very few students knew the term. Two years later, a new cohort was not only entirely familiar with the concept (and there were ten nationalities in the class), but most had firm opinions about it. Some considered the hygge-lover to be 'the new hipster'; others were more negative, criticising a perceived hypocrisy in the pervasive 'selling' of an allegedly anti-materialist practice. As one student wrote, 'Hygge has capitalised on the vulnerabilities and anxieties of the Anglophone masses, promising the most tantalising form of gratification. Brilliantly clever yet morally wrong, hyggeas-commodity has proved to be an ingenious yet dangerous concept' ${ }^{2}$ This characterisation of hygge seemed so far removed from the original Danish understanding of the term that we began to ask questions. What had happened to hygge in its journey from one culture to another? What frameworks could be constructed to understand it in its new iteration? And finally, how could we make 
sense of the enormous amount of visual data generated by its print and on-line mediation? $?^{3}$

\section{The hygge phenomenon}

First it was necessary to understand the mechanics of the phenomenon which, in a matter of a few months, had come from seemingly nowhere to dominate British bookshops and social media platforms. According to Guardian journalist Charlotte Higgins, the hygge trend was 'concocted in the laboratory of London publishing houses, and then disseminated through the ready collaboration of an enthusiastic neophile press'. ${ }^{4}$ It began with a single article in the BBC News Magazine in $2015^{5}$ and reached a peak in the autumn of 2016 with a flurry of coffee-table books with similar titles, several of which were swiftly translated into a variety of languages. ${ }^{6}$ Retailers like John Lewis jumped on the 'Scandwagon' of hyggelige winter displays and by the end of the year there were inevitable parodies as well. ${ }^{7}$ The term narrowly missed being dubbed the Oxford Dictionary's word of the year (it lost to 'post-truth'). Some media commentators suggested that the reason for its sudden popularity was encapsulated in the other short-listed words 'alt-right', 'Brexiteer' and 'woke'; hygge, it was argued, represented a desire for safety and comfort in a year that saw the rise of racism, the election of Trump and the Brexit referendum. Three years on, we perhaps have the distance to reflect on this cultural appropriation in a more objective and nuanced way.

Most of the recent English writing on hygge devotes strenuous efforts to explaining the term and its lack of an adequate translation, usually settling on approximations like 'cosiness' or 'togetherness', or resorting to other language equivalents like the German Gemütlichkeit or Dutch gezelligheid. ${ }^{8}$ For Danes themselves, the ubiquity of the term, its embedded-ness in everyday life and its linguistic flexibility ${ }^{9}$ make it an experiential, but generally silent, witness of collective social practices that many see as a fundamental part of the Danish spirit or folkesjoel. And yet, for all that hygge - in both its Danish and international variants - has countless practitioners, spokespeople and critical commentators, it has few theoreticians. Twentieth-century literary and artistic research largely dismissed it as a low-level sentiment, unaligned with the existential disillusionment and melancholy that were seen as the true face of modernity. The best existing studies are more recent and approach it instead from the viewpoint of linguistics or anthropology. These are written by Danes and predate the Anglophone appropriation. ${ }^{10}$ Carsten Levisen, for example, has argued that the term's semantics can best be understood in relation to the cultural values it construes, notably the distinctive social ethos that emerged in Denmark in the late nineteenth and early twentieth centuries. ${ }^{11}$ Anthropologist Jeppe Trolle Linnet, on the other hand, has examined the behaviours associated with hygge, discussing it as a vehicle of mutual social control in an egalitarian culture that enforces the Danish welfare state's normativity. ${ }^{12}$ Mikkel Bille, building on Judith Hansen's definition of hygge, has also used anthropological research to explore the pivotal role of affective light in creating 
specific types of atmosphere that connote hygge's tryghed (secureness) and fallesskab (community). ${ }^{13}$

Hygge's affective component has even led to claims that it is now actively used as a form of 'soft power', deployed alongside other Danish cultural products in pursuit of geopolitical goals. ${ }^{14}$ Internationally, it has been linked to the success of the Danish social model that has contributed to the country's high rankings in the UN's annual World Happiness Report, while in Denmark it is used by Dansk Folkeparti (the Danish People's Party) to affirm national cohesion in the face of perceived immigration threats. What is not recognised in the Anglophone appropriation is that hygge is a marker of Danish cultural values which have themselves been the focus, since the nineteenth century, of polarised debate between conservative national romanticism and critical cultural radicalism. In their support for or rejection of hygge, these viewpoints found distinctive aesthetic expression in the field of design, particularly that related to the home. The recent startling emergence of a third viewpoint on hygge as a lifestyle position, a phenomenon over which initially the baffled Danes had little control (while at the same time finding their social habits and designed interiors the focus of world attention), demands a different framework for analysis. Design history offers one possible approach.

\section{Design 'mythologies'}

This paper will look at 'designed' representations of hygge, using examples from both the historical Danish debate and the recent British trend, to argue that while the visual signifiers of the British version are in many ways similar to Danish ones, the signifieds are surprisingly different. ${ }^{15}$ To help understand the reasons for this, we will invoke Roland Barthes' notion of mythologies - with its exposure of falsely 'normative' values ${ }^{16}$ - to suggest that hygge owes its rapid and remarkable success in the international arena to the existence of prior myths. In other words, it fell on fertile ground. While media commentators like to talk about the 'Scandimania' that has swept Britain since the first series of Søren Sveistrup's The Killing, ${ }^{17}$ design historians can probe further back and argue that hygge is nourished by the careful branding of 'the North' that has accompanied the commercial promotion of Scandinavian Design since the Second World War. ${ }^{18}$ Over the last fifteen years, these master narratives have been exposed and deconstructed by design historians like Kjetil Fallan and Kevin Davies who have challenged the narrow, essentialist understanding of Nordic design culture they produce and argued that design history needs to embrace alternative histories. ${ }^{19}$

Central to such critiques - and their frequent reference to the narratives of Scandinavian Design as 'myths' - is Barthes' idea of 'myth' as something wrongly taken to be an essential truth. In theorising 'givens' (in his case everyday 'things' from French culture) as networks of signs, Barthes saw myth as a second-order semiotic system which, when decoded, reveals hidden ideological structures. By making particular signs appear natural, myth renders invisible the history or context 
that has given rise to them. Critics like Davies have argued that this is largely what happened with the enduring 'givens' of Scandinavian Design, seen in the undiscriminating repetition of descriptors like 'democratic', 'authentic', 'humane' or 'restrained', together with the discourse of the noble primitive (termed 'Homo Scandinavicus' by Roger Connah) that romanticises a special relationship to landscape, natural materials and craft skills. ${ }^{20}$ Davies and others have challenged such stereotypes, firstly by addressing the design objects themselves and, secondly, by examining the narrative frameworks that surrounded them, in order to argue that the generation of such labels owed as much to the rhetoric of political, cultural and economic marketing as to the inherent qualities of the objects. The business historian Per H. Hansen, for example, in his investigation of assigned narratives in the branding of 'Danish Modern', draws on the theories of both Barthes and Jean Baudrillard to make the powerful claim that

the international success of Danish Modern was not due to the essential beauty of the furniture, but to the concerted efforts of a social network to assign certain meanings to concepts like "Danish Modern" and "Danish Design". In other words, there was no Danish Modern until it was constructed by a narrative. ${ }^{21}$

More recently, Anders V. Munch has coined the term 'self-exoticization' to explore how Danish designers and writers have 'performed' national values into the mirror of foreign expectations. ${ }^{22}$

We argue that the recent Anglophone fascination with hygge can be explained by the legacy of such frameworks, but with one important difference: while the Nordic countries were complicit in the creation of myths of Scandinavian Design, the aestheticised lifestyling of hygge emerged in London. This commercialised mediation took the Danes somewhat by surprise, although they were quick to respond when asked to write books on the subject by London editors and soon realised the public relations capital embedded in the linking of hygge to Denmark's success in the World Happiness rankings. ${ }^{23}$

Our discussion of hygge falls into two parts. The first situates the source Danish concept within broader narratives of Danish identity since the nineteenth century. Countering the claim that hygge has always enjoyed a positive social consensus among Danes, it demonstrates that it was also the target of artistic and literary critique, particularly as played out in ideas about the designed interior. The second part looks at how the media-savvy, aesthetic styling strategies of British hygge draw, self-consciously or not, on the imprinted legacies of Scandinavian Design as marketed in Britain since the Second World War. Here a carefully-crafted, normative rhetoric is given luscious visual form in painstakingly staged photographs: hygge's closecropped 'object-selfies' and complicit human tableaux speak to a media-aware public through an idealised, commoditised and 'Instagrammable' mode of lifestyle branding. In the paradox of its professed anti-materialism, this is an artificial form of 
consumable and performative hygge which offers a fascinating contemporary example of the continued commoditisation of the Scandinavian myth.

\section{The historical context: hygge as a battleground for cultural values}

In the years following the Second World War, English-speaking journalists, diplomats and cultural commentators constructed an idea of Danish national identity on the basis of selective history, landscape, provincial town life, moderate weather and patterns of social behaviour. Most opined that the Danish national character embraces consensus and harmony. This was justified through a narrative that cited the Danes' origins as brutal, seafaring Vikings, before skirting hastily over the next millennium to the nineteenth century when the nation experienced a series of territorial, economic and moral disasters. In the cold light of defeat the Danes became humble, their newfound introspection and self-consciousness expressed in the poetry of Adam Oehlenschläger and N. F. S. Grundtvig. ${ }^{24}$ This inwards-looking provincialism, so the narrative goes, opened the way to a worship of the home as the centre of family life, synonymous with 'security' and 'interiority' in an unstable world. In its embrace of human-centred interactions, it evoked Ferdinand Tönnies' notion of Gemeinschaft (community), ${ }^{25}$ idealising the home as trygt, triveligt og hyggeligt (a haven of safety, well-being and hygge). Increasingly, being Danish was to be defined in terms of one's smallness. ${ }^{26}$ Such an interpretation is in line with Danish accounts of the nineteenth century, which highlight how the country's art and literature nurtured the Romantic distinction between a psychologically and morally charged 'inner space' and the 'harsh' outside world.

The metaphor of the 'home', encouraged by wider currents that included the writings of the Swedish social reformer Ellen Key, continued into the Scandinavian social democratic models of the twentieth century with their vision of the welfare state as the 'people's home'. ${ }^{27}$ It entered the utopian rhetoric of modernist design which portrayed the ideal home as a microcosm of society, a vehicle for nurturing a better form of social behaviour. One of the enduring narratives of Scandinavian (particularly Danish) Functionalism is that it tempered the cultural radicalism and perceived sterility of the International Style with a warm humanism that recognised the value of tradition, national building customs, natural materials and 'honest' craft. Simply put, it made 'homely' the rational aims of modernism and brought hygge into the private space as a retreat from the public environment (fig. 1). This 'gentler' Functionalist tradition has been linked to the success story of the Danish (and Nordic) welfare state, with its economic and political stability, transparent institutions and high quality of life.

It is a neatly-packaged narrative, and one that lends itself to easy marketing of Denmark as a social and cultural utopia that through the centuries has venerated the secure 'life in the inglenook corner', as the literary critic Georg Brandes expressed it in $1889 .{ }^{28}$ But it allows no recognition of the fact that this national 'consensus' was in fact fractured. In the late nineteenth century, hygge and the home became a 
battleground between conservative bourgeois romanticism and cultural radicalism. For Brandes, who led the fight for Det Moderne Gennembrud (the modern breakthrough), the veneration of hygge epitomised the nostalgia and mediocrity of Biedermeier culture: 'To the home is linked the concept of "hyggelig-ness", an untranslatable word that has its source in the happiness of sitting warmly and nauseously within four walls'. ${ }^{29}$ Brandes saw hygge as toothless, but not harmless: a cloak of indolence for bourgeois, self-satisfied delusions that celebrated the banal and trivial and led to cultural stagnation. He cast his modern breakthrough in terms of a struggle between a closed and open outlook, between passivity and action and between a stifling idealisation of the everyday and an embracing of the foreign and exotic. With his binaries he provided a list of properties that have been attributed to hygge ever since. Seen as a retreat from the outlandish and uncontrollable, hygge for its defenders offered a survival mechanism against the angst-inducing conditions of modernity (epitomising the uhyggelig or unhomely/ uncomfortable). ${ }^{30}$

Brandes' cultural-radical successors showed more ambivalence in relation to the phenomenon. On a surface level, the material stage-setting of hygge was criticised by modernist designers for its perceived bourgeois preoccupation with unnecessary clutter: cushions, textiles, pictures and ornaments. ${ }^{31}$ They rejected the middle-class klunkestil (tassel style), with its heavy furniture, dust-gathering upholstery and crowded surfaces, and embraced the crisp, hygienic forms of Functionalism. Ostensibly, then, the design rhetoric of modernism - with its open-plan spaces, public transparency, industrial materials and mass production - seems diametrically opposed to the descriptors of hygge, which evoke small, intimate spaces, the handmade, the personal and the inherited. Yet Scandinavian modernists did not so much jettison hygge as approach it in a new light. One example of this is the nuanced critique by the left-wing thinker and designer Poul Henningsen who viewed hygge as imbricated in class power relations. His critical writings discussed the inherited practices and material representation of hygge as a form of false consciousness contributing to the repression of the poorly educated classes. He argued that in their imitation of the ornamented styles and bric-a-brac of the bourgeoisie, the lower classes demonstrated a lack of cultural independence and upwards mobility, a gesture of powerlessness that he believed could be remedied through education and information. Advocating instead affordable, functional and rational design, Henningsen did not set out to abolish hygge, but rather to promote its authenticity as a practice that should be disassociated from class, rather than incrementally related to the plushness of upholstery and intricacy of ornamentation. ${ }^{32}$ An example of this in practice was Henningsen's ideas concerning the role of better lighting in creating cleaner, more beautiful homes; his multi-shaded table and hanging lamps, with their circular pools of affective light, have become universally associated with the mise-en-scène of hygge (fig. 2).

Henningsen was not alone in recasting ideas of the material realisation of hygge. Other modernist designers, particularly Arne Jacobsen and Poul Kjærholm, overtly 
de-romanticised their furniture in a rejection of deep-rooted bourgeois design traditions, deliberately eschewing ornament, exposing construction principles and using industrial materials like steel and glass. Some found it more difficult. As a young idealist, the Norwegian architect Odd Brochmann subscribed to this 'freeing' from tradition's quagmire of symbolic hygge props, designing 'rooms as crisp, clear quadrilaterals without any hint of nooks and crannies that could give the feeling of shelter and intimacy.' Yet he later recognised that

one element offered trouble: the hearth. We were Norwegian after all. And so we skirted around the issue and put forward all kinds of sensible arguments to keep it $[\ldots]$ But deep in our conscience muttered a voice that here we were giving the middle finger to the Devil. All the more eagerly we replaced the wood of furniture with blank, hard steel, and the potted flowers on the windowsill with spikey, ugly cacti - if they were not banished altogether. All the same, we knew that temptation always lay in wait, so that in ageing we might be tempted to seek hygge ourselves. ${ }^{33}$

Brochmann acknowledged that his blind faith in Functionalism had led him to deny the value of hygge, seeing it only as a form of petty bourgeois expression rather than a genuine human need. His realisation that the cold impersonality of modernism should and could be tempered by an acknowledgment of hygge has become a central tenet of the humanist narrative of Scandinavian Functionalism.

To summarise then, the main historical criticisms levelled at hygge by writers and designers targeted not so much the concept itself as its forced, simulated or artificial performance, particularly when used as an expression of bourgeois parochialism or national navel-gazing. Hygge has also been critiqued by feminist writers for subtly reinforcing gender inequalities, for example by the 1960s novelist Tove Ditlevsen who gently parodied hygge's claustrophobic home-making rituals as a form of culturally sanctioned social control. ${ }^{34}$ This class-based distinction between 'genuine' hygge (a positively charged concept) and hygge as a performed simulacrum still characterises Danish attitudes today, according to Linnet. His anthropological research suggests that most Danes believe that hygge does not rely on material goods, indeed slips away if too consciously staged, citing criticisms of the upper classes who

have allegedly lost the sense of sympathetic, honest immediacy to social interaction that hygge represents [...], people perceive the status-oriented, aesthetic, and symbolic side of consumption as detracting from hygge, which they idealize as belonging to the realm of the "ordinary". ${ }^{35}$

Nonetheless, there is an interesting paradox underlying hygge's professed antimaterialism and its mise-en-scène: willingly or unwillingly, hygge does often implicate props, usually related to household design. ${ }^{36}$ Perhaps the issue should be approached instead by analysing how the symbolic or ideological values of these 
props have been transferred to hygge, as in Brandes' cultural-radical critique of claustrophobic bourgeois interiors, or, conversely, in the way that hygge is currently used to reinforce ideas of a homogenous and egalitarian (i.e. middle-class) Danish culture. ${ }^{37}$ Props have particular prominence in the social media-friendly images of the British hygge trend, their meanings mediated through their photographic staging. Consumers are encouraged to 'buy in' to a vision of Danish happiness, accessible via self-help books and the array of desirable products they contain, all articulated in the comfortingly familiar aesthetic language of Nordic design. The settings presented in these images contain a network of signs that evoke positive stereotypes of Scandinavia as marketed in Britain since the Second World War. We will therefore turn now to consider how the legacy of such mythologies has influenced the framing of British hygge.

\section{Design myths and the British mediation of Danish hygge}

The gently persuasive discourse of Scandinavian Design has played a significant role in the soft power geopolitics of the last seventy years. During the Cold War it was used by various Nordic agencies to promote an ideal of pan-Scandinavian unity (most notably in Ulf Hård af Segerstad's introduction to his 1961 book Scandinavian Design, which he entitled 'Four Countries - One Esthetic Culture'), portraying the region as a social democratic buffer to the totalitarian regimes of the Eastern Bloc. ${ }^{38}$ The Finns, in particular, harnessed design to demonstrate their Western cultural and ideological allegiance, in the words of one 1950s American commentator 'using glassware, textiles and ceramics as "weapons" against a creeping communism that still threatens their independence'. ${ }^{39}$ One might ask if British consumers of the time were buying a product or an imagined political ideal, particularly in the post-war context of the emerging welfare state; certainly, the English-speaking world played a crucial role in the branding of the concept. As Davies has pointed out, the term 'Scandinavian Design' was coined in Britain, first appearing as the title of an exhibition at Heal's in London in 1951 and swiftly adopted by a wave of very successful international exhibitions and trade fairs over the next two decades. ${ }^{40}$ Its core messages were forged in the complicit rhetoric of Western commentators and Scandinavian cultural diplomats, offering a utopian vision of a society that had largely escaped the ills of industrial production and neatly solved the problems of dehumanising Fordism and Taylorism. To inanimate design objects were attributed qualities more suited to sentient beings, presented as 'honest', 'authentic', 'ingenious' and 'sensible'. Elizabeth Gordon, editor of Home Beautiful and organiser of the influential Design in Scandinavia exhibition that toured North America between 1954-57, championed the 'democratic' nature of the exhibited objects, arguing that Scandinavians and Americans 'are both deeply democratic people'. ${ }^{41}$ Post-war Brits, on the other hand, hampered by Utility furniture regulations, liked the affordability of Finmar-supplied Finnish and Danish furniture, marketed at an expanding middle class who, like the Danes, socialised in the home. ${ }^{42}$ In meticulously prepared promotional tracts, Scandinavian wordsmiths like Hård af Segerstad and Gotthard Johansson glossed over historical conflicts to paint an attractive portrait of a region unified by 
shared values, traditions and outlook. ${ }^{43}$ A central theme of these exhibitions was the home and its dominant presence in Nordic mentality, society and culture:

To the Dane, Finn, Norwegian or Swede, the home holds a very special position in the center of his existence $[\ldots]$ the dwelling there is regarded not only as a place where one eats and sleeps but as the true frame around family life. Further south one meets friends in restaurants and inns, but in the North you invite them to your home. That's why the house and its furnishings are of special interest to everyone [...] Private homes rather than museums and collections are the first place to look for examples of modern Nordic applied arts. That's why form in Scandinavia can be regarded as a genuine expression of a democratic aesthetic culture. ${ }^{44}$

While on a political level this allowed a subtle championing of the Nordic social democratic model, it also provided an effective marketing framework for the main economic goods of Scandinavian Design: furniture and household objects. Here the emphasis was on the way that age-old craft traditions and an affinity for natural materials had been made relevant for the present day, bringing warmth and human values to the functional advantages of modern design. Gordon, for example, extolling the tactility, softness and lyricism of works by Scandinavian designers, stated, 'Home is their center - and people are the center of their homes. Their design is warm and human. Therefore it is personal, national and universal'. ${ }^{45}$

More relevant to the specifically British context of Danish design myths is the reinforcing of ideas of home-centred intimacy and restraint in the 1968 exhibition Two Centuries of Danish Design organised by the Danish Society of Arts and Crafts and Industrial Design at the Victoria and Albert Museum, which later travelled to Glasgow and Manchester (fig. 3). Its catalogue, authored by Esbjørn Hiort, former director of Den Permanente (Copenhagen's association of design retailers), stated

[The Danes] produce art and architecture of a more intimate kind. Where the great nations have played symphonies, the Danes have preferred to play chamber music. Their works have thereby become less grandiose, but on the other hand often more human too [...] The Danish mentality [...] is typified by a dislike for extremes, by a preference for moderation. This has left its mark on Danish applied art down through the ages, and continues to exercise its influence to this day. ${ }^{46}$

While none of these accounts, to our knowledge, mention the word hygge (indeed few of them use any Scandinavian terms), their focus on the home, modesty, humancentredness and dislike of extremes are all values of hygge as identified by Linnet and Levisen. Whether any of these qualities were quantifiably embedded in the designed objects themselves is a moot point and one that has been thoughtfully explored by Fallan, Davies, Hansen, Guldberg and others. What concerns us here is the success of 
the narrative, the way in which the British and American public were skilfully coerced into reading such meanings in the things themselves. Importantly, the strength of the Scandinavian Design myth has meant that, ever since, the Englishspeaking world has somewhat blindly accepted that anything that comes from this idealised 'other' has to be good. Harri Kalha discusses the appeal of the 'other' in terms of cold-warm dynamics, using Susan Stewart's term 'warm objects of alterity' and her suggestion that 'a metonymical linkage exists between the other and the anterior realm of childhood' to explain the attraction of Scandinavian Design. Quoting Nelson Graburn, Kalha argues that 'one gains prestige by association with these objects [...] there is a cachet connected with international travel, exploration, multiculturalism [..] at the same time, there is the nostalgic input of the handmade in a "plastic world". ${ }^{47}$ This does not fully explain the rapidity with which the hygge trend caught on in Britain in 2016 (behavioural psychology and media studies might be better placed to conduct this kind of analysis), but it does provide some context. In particular, it underpins the material vocabularies used for the visual mediation of hygge, as promoted in lifestyle books, magazine articles and social media.

\section{The appeal of New Nordic}

These seductive photographic images, honed to the sharing platforms of Instagram or Pinterest and a staple of interior design magazines, connect to a generic 'Nordic' look that draws on the vocabularies and ethical values of recent concepts like 'New Nordic' or 'Nordic Cool'. As exemplified by design companies such as Muuto or Normann Copenhagen, or by gastronomic entrepreneurs like Claus Meyer and René Redzepi, these emphasise an 'ur-Nordic' connection to nature that both evokes the rhetoric of mid-century design and opens the door to the distinct blending of Nordic exoticism and global market orientation that images of hygge encapsulate. With its ethos of back-to-nature slow living, simplicity and honesty, New Nordic - despite its global reach and commercial end-goals - connotes a recovery of lost human values in a modern age that is not dissimilar to the emphasis on preserved tradition and slow craft skills in Danish Modern. ${ }^{48}$ In line with Barthes' idea of 'myth', it offers an identity-giving metanarrative of a shared origin, a counter-myth to the rational efficiency and digitisation of the modern world. It is presented to the global public through an aesthetically attractive, photogenic language, as exemplified in Meyer and Redzepi's 2010 book NOMA Time and Place in Nordic Cuisine (illustrated with Ditte Isager's beautifully choreographed photographs of isolated, dream-like Nordic landscapes), or in the recently opened Noma 2.0 in Copenhagen (2018), designed by Bjarke Ingels according to the typology of the Nordic shieling or sceter (fig. 4). Both offer a carefully orchestrated Gesamtkunstwerk of Nordic time and space, engaging visual aesthetics as much as taste or smell in their emphasis on local, hand-crafted materiality. Noma 2.0 unashamedly builds on the enduring tropes of Danish design: from the 'community' of clustered buildings set in an open relationship to nature, to the homely atmosphere of the dining area, the mid-century furniture references and the hand-crafted ceramics, glass and natural textiles. ${ }^{49}$ 
The staging of British hygge: key characteristics

New Nordic's connotations of a return to simple elements, slow living and shared human values are echoed in the mise-en-scène of British hygge. Formed in the tasteshaping moulds of London publishing houses and marketed primarily at an urban, relatively affluent consumer, British hygge offers an escape into photogenic interior spaces. Three key characteristics emerge from a survey of the visual images associated with the trend. ${ }^{50}$ Firstly, British hygge is unambiguously staged in the home, whether an urban flat or a rural retreat with windows open to the sea or forest. Interiors are decorated in calm, cool colours and sparsely furnished with natural or 'earthy' materials and a range of carefully selected props: an open fireplace or woodburning stove, candles, woollen socks, blankets and cushions, books, hand-crafted or Danish Modern furniture, picturesque bric-a-brac and home baking (fig. 5). These signify a rejection of the industrially manufactured, the digital and the mass-produced, implying a preference for originality, creativity and the handmade that accords well with British middle-class nostalgia for the Arts and Crafts movement. It also, in a sense, continues the romantic primitivism that characterised the British post-war reception of Scandinavian Design, the idea that 'Homo Scandinavicus' has somehow preserved 'proper' human values in the face of deleterious modernity. Hygge stages activities that demand time, involvement and patience and thus give an impression of mental presence; it 'performs' the rejection of conventional consumerism and waged work, even though it is mostly enacted in leisure hours.

Secondly, the photographs signify that the inhabitants of these spaces possess certain skills and privileges. This is seen both when they are directly present and when they perform by proxy through the objects occupying their hygge space. The actors of hygge are inevitably young, beautiful, happy and multi-ethnic; their well cared-for children never carry electronic devices and actively participate in connected activities that stimulate the senses and the spirit. A frequent motif is of a group of family or friends engaged in shared conversation over freshly-prepared food around a dining table: images like these do not hide their idealisation and pose the question whether the hygge that is being performed is an open or closed party (fig. 6). Setting, props, actors and behaviour contain coded signs designed to appeal to a shared set of preferences: the educated, globally-oriented target audience is exhorted to join this paradoxical attempt to materialise a kind of anti-materialism, through which it can be initiated into the taste fellowship conveyed by the images. Pierre Bourdieu discussed this dynamic in La Distinction where he demonstrated how taste and lifestyle preferences function as a kind of positioning in a socio-cultural hierarchy. ${ }^{51}$ It is the target group that is of particular interest here, as it highlights a break from traditional mediatised iterations of Danish hygge as a quintessential characteristic of the small nation's identity. Moreover, the taste-aware, internationally-oriented consumer implied by British hygge contrasts strongly with the recent ideological use of the concept by the reactionary right-wing Danish People's Party (DF), which often refers back to the iconography used to brand Denmark in the 1950s and 60s. Promoting the idea that 'Danish-ness' is the sanctuary of wholesome national values currently under 
threat from foreign pressures, DF has portrayed itself as the protector of this bourgeois retro hygge. Its media imagery prioritises a nostalgic past and sentimentalised folk culture, conveyed through unambiguously 'Danish' signs such as the Dannebrog (Danish flag), folksy cross-stitch depictions of Dybbøl Mill (a symbol of Danish resistance against the Germans), cosy allotment gardens and roast pork with parsley sauce.

This simple, ideologically charged language of value symbols, shared by many who maintain reactionary beliefs across national boundaries, also contrasts with the third key feature of British images of hygge: their relatively complex visual communication. They speak specifically to a style-conscious and media-aware audience who can decode the aesthetic references embodied in carefully staged object-selfie still lifes and coordinated languages of colour, form and material (fig. 7). The intended consumers are aware, subliminally if not consciously, of the 'good taste' implied by Nordic minimalism and its embracing of the sense-qualities of material things, willingly projecting themselves into the book-led lifestyling of hygge with its promise of the calm and meaningful life. This conceptualisation, inevitably distanced from clichéd DF images of the phenomenon as a national tribal ritual, appeals to a cosmopolitan throng of social media users who view it as something carefully practised, prepared and performed. In contrast to the experiential dimension of the original Danish concept (understood as a form of effortless social pleasure), British hygge is associated with taste and know-how. Commentators refer to it as an art ('the art of creating intimacy') and it is studied, purchased and consumed through subtle product placement in books and other visual media. Running through all this is a meticulous attention to staging. As Barthes pointed out, a mythology 'harmonises with the world, not as it is, but as it wants to create itself' ${ }^{52}$

\section{Conclusion}

While Danish hygge is an ordinary, omnipresent aspect of collective social practices, the Anglophone version is a media-driven mythology that, in a Barthian sense, both normalises a fiction and masks its history. When unpacked, it reveals its relationship to many of the unpronounced subtexts of 1950s design exhibitions. The internationally marketed variant of Scandinavian Design was, and is, elitist and targeted a monied, middle-class, educated consumer base. It crafted reassuring humanist narratives to support its distinctive characteristics, mapping inanimate objects to sentient needs and evoking 'meaningful' relationships to nature, the home and fundamental human values; its legacy can be felt in many of the key signs and connoted values of the hygge phenomenon. But while Scandinavian Design maintains its reified status in the British cultural consciousness, hygge has seen a parodic and critical backlash, possibly because today's young, media-literate consumers are so used to decoding images that they simply see through the idealised narrative. This was summed up in the opinions of the university students mentioned at the start of this article who criticised British hygge for ignoring deep-seated inequalities of class and wealth. They condemned its hypocritical marketing agenda that convinced 
austerity Britain to 'disengage' from the lure of consumerism by purchasing rule books and objects that allegedly generate happiness. They also pointed to critiques of Danish hygge as fostering insularity and exclusionism, as a means of social control to suppress individuality or dissent, and as underpinning a reluctance to discuss thorny issues or become involved in necessary conflict. ${ }^{53}$

Hygge has, moreover, generated interesting questions about the relationship between globalised trend and national identity. The Brits, as the agents of hygge's international dissemination, have globalised the concept-as-commodity. This has led the Danes to reinforce it more decisively as a treasured national marker, in Levisen's terms a 'cultural keyword' and 'quintessential Danish social value'. ${ }^{54}$ They have realised its economic and political currency, particularly in tandem with their branding as world happiness experts. But now other countries have sought to cash in on the concept's cultural capital: Swedish lagom, Japanese ikigai and Norwegian friluftsliv all battle for supremacy in the lucrative lifestyling market. 2018 even saw the unashamedly commercial launch, supported by the Scottish Tourist Board, of the contrived Scottish version of hygge known as coorie, accompanied by a panoply of purchasable design products. ${ }^{55}$ With its international dimensions, it was perhaps inevitable that hygge should also be brought into the Brexit debate. A few months after the 2016 referendum, a tongue-in-cheek Telegraph article, written at the height of the bookpublishing wave, denounced hygge as 'a conspiracy. A sly ploy to drug us with pastry, lull us into a state of quasi-hibernation and bring about our supine quiescence at a time when we need to stay focused. ${ }^{56}$ This hostility to Danish cultural soft power was nothing new. Davies points out that at the height of popularity of Danish Modern 'it was the reactionary Daily Telegraph reading sector of the population, what Reyner Banham [...] referred to as the "Blimp lobby", that grumbled about it. ${ }^{57}$

In conclusion, hygge as a vehicle of inter-cultural transferral is a striking case study of how meaning is generated and shifts by relocation, and how the signs through which it manifests itself can reveal more about the receiving culture than the source concept. In the British mediation of hygge, it speaks to London-driven consumer trends, to lifestyling as commodity and to skilful product placement, ultimately appealing to a left-thinking, middle-class elite which has the funds - and importantly the leisure time - to perform hyggelige situations. Marketing it as a utopian, national, Danish concept, cleverly linked to aspirational happiness, has allowed it to become, rather like Scandinavian Design, a global brand underpinned by mythologies.

\section{Figure Legends}

Fig. 1: Watercolour illustration of the living area of Karen and Ebbe Clemmensen's own home, Solbakkevej 57, Gentofte, 1953. The architect couple paid particular attention to the 'hygge corner', with its inbuilt sofa, Kaare Klint Safari Chairs and wood-burner. The pine ceiling and light colour palette further enhanced the warm 
intimacy of the living area, contrasting with the large windows to the garden. (C) Danmarks Kunstbibliotek

Fig. 2: Børge Mogensen, interior of his own home, Soløsevej 37, Gentofte, 1957. This epitomises the humanist rhetoric of mid-century Danish Modern, with its use of 'warm' natural materials, craft skills (embodied in the Shaker references of Mogensen's J39 chairs) and the affective lighting of the PH5 lamp. (C) Mads Mogensen

Fig. 3: A Century of Danish Design, catalogue of an exhibition organised by the Danish Society of Arts and Crafts and Industrial Design, 1968. Keld HelmerPetersen's distinctly minimalist cover photograph conveys the de-romanticisation of hygge by Danish Modern designers like Poul Kjærholm (PK9 chairs and PK54 table), Poul Henningsen (Cone Chandelier), Lis Ahlman and Børge Mogensen (carpet).

Fig. 4: Bjarke Ingels Group, Noma 2.0., Copenhagen, 2018. The restaurant's dining area, with its heavy oak ceiling, references the typology of old Danish barns. David Thulstrup's furniture clearly nods to mid-century Danish Design, while other objects in the room (plates, glassware etc) were meticulously crafted by Danish/ Nordic designers. C COAST Rasmus Hjortshøj

Fig. 5: A stock hygge image used by on-line articles. Its curated informality and carefully selected props create a paradoxical tension between consumer aspiration and hygge's professed 'naturalness' and anti-materialism. Adobe Stock image

Fig. 6: A gathering of friends and family around a meal table is often considered quintessential Danish hygge. The Instagrammable version seen here stages a closeknit circle in a homely interior furnished with an enviable range of mid-century Danish design. (C) Anders Forup / @handcraftedcph

Fig. 7: Illustrations in English-language hygge books frequently offer a blend of staged interiors and 'object-selfies'. These images, from books by Søderberg and Brits, show the careful palette of 'Nordic' living spaces, materials, colours and subtle product placement that underpins the aestheticised life-styling of the British hygge trend. (C) Peter Kragballe and (C) Susan Bell

\footnotetext{
${ }^{1}$ As defined by J. T. Linnet, 'Money Can’t Buy Me Hygge: Danish Middle-Class Consumption, Egalitarianism, and the Sanctity of Inner Space', in Social Analysis: The International Journal of Social and Cultural Practice, vol. 55, issue 2, Summer 2011, p. 21.

2 L. Chester, 'What is hygge and has it changed over the past two years?', unpublished student essay, University of St Andrews, 2018.

${ }^{3}$ For a discussion of design history's interest in mediation, and the role of channels such as magazines and advice literature in mediating between producers and consumers, see G. Lees-Maffei, 'The Production-Consumption-Mediation Paradigm', Journal of Design History, vol. 22, no. 4, 2009, pp. 351-376.
} 
${ }^{4}$ C. Higgins, 'The hygge conspiracy. The long read', The Guardian, 22 November 2016.

5 J. Parkinson, 'Hygge: A heart-warming lesson from Denmark', BBC News Magazine, 2 October 2015.

${ }^{6}$ A small selection of examples include: M. Wiking, The Little Book of Hygge: the Danish way to live well, Penguin Life, London, 2016; M. Tourell Søderberg, Hygge: the Danish art of happiness, Michael Joseph, London, 2016; C. Abrahams, Hygge: a celebration of simple pleasures: living the Danish way, Trapeze, London, 2016; L. Thomsen Brits, The Book of Hygge: the Danish art of living well, Ebury Press, London, 2016; S. Johansen, How to Hygge: the secrets of Nordic living, Bluebird, London, 2016.

${ }^{7}$ Notably Dr M. Olsensen of the fictional Aarhus Institute of Wellbeing's Say ja to hygge! How to find your special cosy place, Hodder \& Stoughton, London, 2016.

${ }^{8}$ It is not the intention of this paper to define hygge and its behaviours. For a fair introduction the reader is advised to consult, for example, J. Friedman Hansen, We Are a Little Land. Cultural Assumptions in Danish Everyday Life, Arno Press, New York, 1980; or C. Levisen, 'Roots of Danish sociality: Hygge as a cultural keyword and core cultural value', Cultural Semantics and Social Cognition. A Case-Study on the Danish Universe of Meaning, de Gruyter Mouton, Berlin, 2012, pp. 80-114.

${ }^{9}$ Hygge has notable linguistic flexibility and can be used as a noun (hygge), adjective (hyggelig/t) and verb (at hygge sig).

${ }^{10}$ Although they have been much (mis-)used since, cited as 'scientific' evidence by English-language hygge books and articles.

${ }^{11}$ Levisen, op. cit., p. 80.

${ }^{12}$ Linnet, op. cit., pp. 21-44.

${ }^{13}$ M. Bille, 'Lighting up cosy atmospheres in Denmark', Emotion, Space and Society, vol. 15, 2015, pp. 56-63. J. Friedman Hansen, 'The Proxemics of Danish Daily Life', Studies in the Anthropology of Visual Communication, vol. 3, issue 1, Spring 1976, pp. 52-62.

${ }^{14}$ J. P. Howell \& T. Sundberg, 'Towards an Effective Geopolitics: Soft Power and the Danish Notion of Hygge', Environment, Space, Place, vol. 7, no. 2, Fall 2015, pp. 97-120.

${ }^{15}$ Due to limitations of space, together with the fact that the original hygge trend was London-driven, the paper will focus primarily on British examples rather than the whole international field.

${ }^{16}$ Roland Barthes, Mythologies, Éditions du Seuil, Paris, 1957. Trans. 1972 by Jonathan Cape Ltd, New York, The Noonday Press.

${ }^{17}$ 2007, first aired in the UK in 2011.

${ }^{18}$ Our capitalisation of 'Scandinavian Design' is deliberate, referring to the carefully curated 'brand' of design objects promoted internationally in the post-war period. While 'Scandinavia', strictly speaking, only refers to Sweden, Norway and Denmark, the international exhibitions of the 1950s used the label to designate the production of all the Nordic countries, paralleling the emergence of the political idea of a collective Scandinavia.

${ }^{19}$ For example: K. Fallan [ed.], Scandinavian Design: alternative histories, Berg, London, 2012; K. Davies, 'Marketing Ploy or Democratic Ideal? On the Mythology of Scandinavian design', in W. Halén and K. Wickman (eds), Scandinavian Design Beyond the Myth. Fifty Years of Design from the Nordic Countries, Arvinius Förlag/ Form Forlag, Stockholm, 2003. This contains a number of essays that examine the role of the foreign and Nordic press, exhibitions, political strategies and market forces in the creation of the English-formulated concept of 'Scandinavian Design'.

${ }^{20} \mathrm{R}$. Connah, Tender is the North, exhibition review in Form Function Finland, January 1993, pp. 1826, cited in Davies, op. cit., p. 105.

${ }^{21}$ P. H. Hansen, 'Networks, Narratives, and New Markets: The Rise and Decline of Danish Modern Furniture Design, 1930-1970', The Business History Review, vol. 80, no. 3, Autumn 2006, pp. 449-450. ${ }^{22}$ A. V. Munch, 'On the Outskirts: the Geography of Design and the Self-exoticization of Danish Design', Journal of Design History, vol. 30, no, 1, 2017.

${ }^{23}$ Higgins, op. cit.. Denmark now offers a number of 'hygge advisors', most famously Meik Wiking of the Happiness Research Institute in Copenhagen. Government websites also stress the link, e.g. Why are Danish people so happy?, https://denmark.dk/people-and-culture/happiness (accessed 6 February 2019).

${ }^{24}$ For more detailed discussion see M. Breunig, 'A whole way of life. Dansk hygge som national livsstilsmarkør og globalt smagsfællesskab', Spring. Tidsskrift for Moderne Dansk Litteratur, no. 44, 2018, pp. 105-126.

${ }^{25}$ F. Tönnies, 'Community and Society', 1887, preface to the second edition (1912), Wilhelmine Germany and the First World War (1890-1918), German History in Documents and Images, 
http://germanhistorydocs.ghi-dc.org/sub document.cfm?document id=751 (accessed 5 February 2019).

${ }^{26}$ Linnet, op. cit., p. 37. Howell \& Sundberg have argued that the deployment of hygge as a form of

'soft power' is particularly well suited to Denmark's 'small state geopolitics' (op. cit., p. 107).

${ }^{27}$ For a thoughtful exploration of how understandings of the 'home' underpinned Scandinavian architectural developments from National Romanticism to Functionalism see Barbara Miller Lane National Romanticism and Modern Architecture in Germany and the Scandinavian Countries, Cambridge University Press, 2002.

28 'Livet i kakkelovnskrogen'. G. Brandes, 'Aristokratisk Radikalisme. En Afhandling om Friedrich Nietzsche', Tilskueren, vol. 6, August 1889, p. 576.

${ }^{29}$ G. Brandes, 'Emigrantlitteraturen', Hovedstrømninger i det 19de Aarhundredes Litteratur,

Gyldendal, Copenhagen, 1872, p. 149.

${ }^{30}$ Breunig, op. cit., p. 110.

${ }^{31}$ Even modern definitions of hygge still link it to furnishings. Gullestad states: 'a cozy home has a wealth of textiles, potted plants, souvenirs, paintings, and photographs'. M. Gullestad, The Art of Social Relations: Essays on Culture, Social Action and Everyday Life in Modern Norway, Scandinavian University Press, Oslo, 1992, p. 80. Quoted by Linnet, op. cit., p. 24.

${ }^{32}$ P. Henningsen, 'Tradition og Modernisme', Kritisk Revy, issue 3, 1927. See also 'Til de triste Modernister', Kritisk Revy, issue 3, 1928. For further discussion, see M. Breunig, Den iscenesatte bolig. Fem studier af hjemliggørelse i det 20. århundrede, Syddansk Universitetsforlag, Odense, 2017, p. 54 onwards.

${ }^{33}$ O. Brochmann, 'Fra kolde hvide vægge til tegl og træ', Om hygge. Ti kronikker, Politiken, Copenhagen, 1965, pp. 70-71.

${ }^{34}$ T. Ditlevsen, 'Sjældent hyggeligt', in Om hygge. Ti kronikker, Politiken, Copenhagen, 1965, pp. 1415.

${ }^{35}$ Linnet, op. cit., pp. 27-28.

${ }^{36}$ Howell \& Sundberg state: 'In line with assemblage and materiality theories, physical objects in ambient settings are required for hygge feelings. Hygge encompasses a range of generally attractive sensory, material, and emotional micro-element assemblages, such as candle-light [...] textured fabrics, blankets, sweaters, rustic homemade food, red wine, akvavit, close friends and meaningful conversations', op. cit., p. 110.

${ }^{37}$ Linnet, op. cit. pp. 29-32.

${ }^{38}$ U. Hård af Segerstad, 'Four Countries - One Æsthetic Culture', Scandinavian Design, Studio Books, London, 1961, pp. 7-9.

${ }^{39}$ H. Heintzen, 'Finns Use Craft Works to Weld Links to West', The Times-Picayune New Orleans States, 6 February 1955. Quoted by H. Kalha, “"Just One of Those Things" - The Design in Scandinavia Exhibition 1954-57', in Halén and Wickman, op. cit., p. 69.

${ }^{40}$ Davies, op. cit., p. 103.

${ }^{41}$ E. Gordon, 'Why the new Scandinavian show is important to America', House Beautiful, February 1954, quoted by Kalha, op. cit., p. 70.

${ }^{42}$ On the marketing and affordability of Scandinavian design in Britain in the 1930s-50s, see K. Davies, 'Finmar and the Furniture of the Future: the Sale of Alvar Aalto's Plywood Furniture in the UK, 1934-39', Journal of Design History, vol. 11, no. 2, 1998; and 'Scandinavian Furniture in Britain: Finmark and the UK Market, 1949-1952', Journal of Design History, vol. 10, no. 1, 1997.

${ }^{43}$ Among recent studies examining the discourses constructed around Scandinavian Design exhibitions see Jørn Guldberg, "Scandinavian Design” as Discourse: The Exhibition Design in Scandinavia, 195457', Design Issues, vol. 27, no. 2, Spring 2011.

${ }^{44}$ Hård af Segerstad, op. cit. pp. 7-8.

${ }^{45}$ Gordon, op. cit..

${ }^{46}$ E. Hiort, 'Arts and Crafts of the $18^{\text {th }}$ and $19^{\text {th }}$ Centuries', in Two Centuries of Danish Design: London, April 18 - June 3 1968, Danish Society of Arts and Crafts and Industrial Design, 1968, pp. 1314. The exhibition, designed by Finn Juhl and re-named A Century of Danish Design, travelled later that year to the Kelvingrove in Glasgow and the Whitworth Art Gallery in Manchester.

${ }^{47}$ Kalha, op. cit. pp. $70-71$.

${ }^{48}$ See N. P. Skou \& A. V. Munch, 'New Nordic and Scandinavian Retro: Reassessment of values and aesthetics in contemporary Nordic Design', Journal of Aesthetics \& Culture, vol. 8, issue 1, 2016.

${ }^{49}$ For further discussion of the new Nordic aesthetic, and Noma in particular, see M. Breunig, 'Nordisk mytologi: En fortids genfortryllelse på restaurant Noma', in S. Kluge et al. Det historiske blik: En 
antologi om historiebrug og historisk metode. Aarhus Universitetsforlag, Aarhus (forthcoming Dec. 2019).

${ }^{50}$ Breunig, op. cit. (2018), pp. 117-122.

${ }^{51}$ P. Bourdieu, La Distinction. Critique sociale du jugement, Éditions de Minuit, Paris, 1979.

${ }^{52}$ Barthes, op. cit., p. 157.

${ }^{53}$ Linnet, op. cit., pp. 32-33.

${ }^{54}$ Levisen, op. cit., p. 80. In 2016 hygge was deemed one of ten core Danish values (alongside the welfare state, gender equality and Christian heritage) in Denmark's Canon - 10 values for the society of the future, formulated by the Minister of Culture, Bertel Haarder. See https://www.danmarkskanon.dk/ (accessed 6 February 2019)

${ }^{55}$ Gabriella Bennett, The Art of Coorie. How to Live Happy the Scottish Way, Black and White Publishing, Edinburgh, 2018

${ }^{56}$ Judith Woods, 'Forget hygge - Brits should be embracing "brygge", The Telegraph, 15 September 2016.

${ }^{57}$ Davies, 'Marketing Ploy or Democratic Ideal?', p. 104. 